\title{
ANALISA RESPON MEKANIK STRUKTUR BATAKO RINGAN DARI BAHAN KOMPOSIT CONCRETE FOAM DIPERKUAT SERAT TKKS TERHADAP BEBAN IMPAK JATUH BEBAS
}

\author{
Randy Brayn ${ }^{1}$, Bustami Syam ${ }^{2}$, Syahrul Abda ${ }^{3}$, M. Sabri ${ }^{4}$. Indra ${ }^{5}$ \\ 1,2,3,4,5 Departemen Teknik Mesin, Fakultas Teknik, Universitas Sumatera Utara \\ Email : randy.stoker69@gmail.com
}

\begin{abstract}
ABSTRAK
Tandan Kosong Kelapa Sawit (TKKS) memiliki nilai untuk direkayasa menjadi material alternatif yang dapat dimanfaatkan dengan alasan masih berlimpahnya bahan baku, mudah diolah menjadi bentuk serat halus, dapat didaur ulang, bebas korosi, tahan dan mampu menyerap suhu panas, serta ekonomis, seperti untuk pembuatan papan partikel. Tujuan penelitian ini untuk menganalisa respon mekanik produk batako ringan dari bahan concrete foam diperkuat serat tandan kosong kelapa sawit (TKKS) akibat beban impak jatuh bebas. Pembuatan batako ringan menggunakan mortar; semen $=30 \%$, pasir $=45 \%$, air $=15 \%$. Lalu ditambahkan bahan pengembang $=7 \%$. Bahan concrete foam ini diberi penguat matriks berupa serat TKKS $=3 \%$. Dimensi batako ringan $600 \times 200 \times 100 \mathrm{~mm}$. Metode penelitian yang dilakukan adalah metode penelitian eksperimen. Data diperoleh melalui pengujian makrostruktur dan impak jatuh bebas. Hasil pengujian impak jatuh bebas ketinggian 0,5 $\mathrm{m}$ tegangan rata-rata $0,0035 \mathrm{MPa}$, tegangan lentur 8,1 MPa dan energi impak 105 joule terjadi patah. ketinggian $1 \mathrm{~m}$ tegangan rata-rata $0,0057 \mathrm{MPa}$, tegangan lentur $12,9 \mathrm{MPa}$ dan energi impak 524,5 joule terjadi patah. ketinggian $1,5 \mathrm{~m}$ tegangan rata-rata $0,0075 \mathrm{MPa}$, tegangan lentur 16,4 MPa dan energi impak 1118 joule terjadi patah. Rata-rata area porositas pada specimen batako ringan adalah $15.19 \%$.
\end{abstract}

Kata kunci: Limbah Tandan Kosong Kelapa Sawit, Material Engineering, Concrete Foam, Beban Impak Jatuh Bebas, Batako Ringan

\section{PENDAHULUAN}

Batako ringan merupakan bahan bangunan yang berupa bata cetak alternatif pengganti batu bata yang tersusun dari komposisi antara pasir, semen portland dan air dengan rasio perbandingan antara semen dan pasir adalah 1:7. Batako ringan difokuskan sebagai konstruksikonstruksi dinding bangunan nonstruktural. Bentuk dari Batako ringan/batu cetak itu sendiri terdiri dari dua jenis, yaitu batu cetak yang berlubang (hollow block) dan batu cetak yang tidak berlubang (solid block) serta mempunyai ukuran yang bervariasi [1].

Batako ringan dari beberapa pengertian diatas dapat ditarik kesimpulan tentang pengertian batako ringan adalah salah satu bahan bangunan yang berupa batu-batuan yang pengerasannya tidak dibakar dengan bahan pembentuk yang berupa campuran pasir, semen, air dan dalam pembuatannya dapat ditambahkan dengan bahan tambah lainnya (additive). Batako ringan dibuat melalui proses pemadatan sehingga menjadi bentuk balok-balok dengan ukuran tertentu.Proses pengerasan batako ringan tanpa melalui pembakaran dan disimpan pada tempat yang lembab atau tidak terkena sinar matahari langsung atau hujan.

Dalam pembentukan batako ringan yang selama ini menggunakan perbandingan antara semen dan pasir 1:7 merupakan komposisi yang cukup besar dalam hal ongkos produksinya. Ongkos produksi dapat dikurangi dengan cara menggantikan komposisi yang ada dan menambah 
bahan pengganti yang lebih murah. Seperti yang kita ketahui fungsi dari batako ringan itu sendiri adalah sebagai pasangan dinding dan bukan menjadi pondasi utama dari sebuah bangunan. Dalam hal ini kita dapat mencoba proses pembuatan Batako ringan dengan menggunakan bahan concrete foam yang diperkuat oleh serat tandan kosong kelapa sawit (TKKS).

TKKS merupakan salah satu limbah terbesar yang dihasilkan dari pengolahan kelapa sawit.TKKS dapat mencapai $230 \mathrm{~kg}$ dari setiap 1 ton pengolahan tandan buah segar [2].

Jumlah ini sangat besar dan menggunung di pabrik-pabrik kelapa sawit.Data ini menunjukkan bahwa begitu banyaknya limbah tandan kosong kelapa sawit ini setiap harinya. Limbah ini dapat kita manfaatkan sehingga dapat mengurangi jumlah limbah yang ada, dengan cara menggunakan tandan kosong kelapa sawit menjadi salah satu bahan tambahan dalam suatu komposisi pembuatan suatu produk [2].

Berdasarkan hasil penelitian Nuzuli fitriadi, batako ringan dengan spesimen tipe B4 dengan ukuran $\varnothing 19 \times 300 \mathrm{~mm}$, jarak impak $50 \mathrm{~mm}$ dan tekanan 0,3 MPa diperoleh tegangan tarik rata-rata sebesar 4,54 $\mathrm{MPa}$ dan nilai modulus elastisitas dinamik 5,82 GPa. Hasil modulus elastisitas concrete foam diperkuat serat TKKS jauh lebih mampu untuk menerima atau menyerap tumbukan akibat beban impak dibandingkan dengan batako ringan yang terdapat di pasaran. Sehingga diperlukan penelitian lebih lanjut mengenai komposisi concrete foam diperkuat serat TKKS yang diterapkan untuk pembuatan batako ringan agar mendapatkan secara detail tegangan yang dapat diserap oleh batako ringan tersebut dengan metode pengujian impak jatuh bebas [3].

\section{TINJAUAN PUSTAKA}

Komposit adalah campuran dua material atau lebih yang dicampur secara makroskopik untuk menghasilkan suatu material baru. Artinya penggabungan sifat-sifat unggul dari pembentuk masih terlihat nyata.

\section{Batako Ringan}

Batako ringan dapat dibagi dalam tiga golongan berdasarkan matrik penyusunan, bentuk dan pemakaiannya.

Batako ringan diperoleh dengan memasukkan udara dalam adukan atau mortar. Dengan demikian akan terjadi pori-pori udara berukuran 0,1-1 mm dalam batakonya. Memiliki berat isi $900-1400 \mathrm{~kg} / \mathrm{m}^{3}$ dan biasanya digunakan untuk keperluan pasangan dinding.

\section{Foam Agent}

Foaming agent adalah bahan yang harus mempunyai formula kimia dengan sifat-sifat antara lain berupa surfactant (surface active agent) dan stabilizer. Foaming agent digunakan sebagai bahan untuk menghasilkan foam (busa) guna mengembangkan volume adonan batako ringan. Bahan ini diharuskan mempunyai kemampuan menyangga pengembangan adonan sampai setting time adonan tercapai (biasanya selama 2 jam sejak proses mixing). Selama 2 jam foam tidak boleh collaps (pecah) sehingga densitas bata ringan dapat dicapai.

\section{Beban Impak Jatuh Bebas}

Beban impak jatuh bebas diperumpamakan sebagai sebuah benda jatuh bebas dari keadaan mula berhenti mengalami pertambahan kecepatan selama benda tersebut jatuh. Perbandingan waktu 
dengan kecepatan seperti terlihat pada tabel 2.2 dan grafik v-t seperti ditunjukkan pada gambar yang merupakan sebuah garis lurus sehingga percepatan seragam

Tabel 2.1. Waktu dan kecepatan benda jatuh

\begin{tabular}{ccccccc}
\hline $\begin{array}{c}\text { Waktu, } \\
t(\mathrm{~s})\end{array}$ & 0 & 1 & 2 & 3 & 4 & 5 \\
\hline $\begin{array}{c}\text { Kecepatan, } \\
V(\mathrm{~m} / \mathrm{s})\end{array}$ & 0 & 9,8 & 19,6 & 29,4 & 39,2 & 49 \\
\hline
\end{tabular}

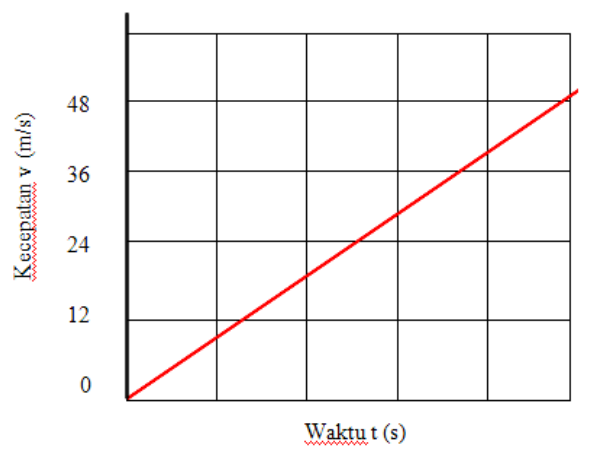

Pada gambar diatas dapat dilihat grafik kecepatan vs waktu. Benda jatuh tanpa kecepatan awal $\left(\mathrm{v}_{\mathrm{o}}=\right.$ $0 \mathrm{~m} / \mathrm{s}$ ). Semakin ke bawah gerak benda semakin cepat. Percepatan yang dialami oleh setiap benda jatuh bebas selalu sama, yakni sama dengan percepatan gravitasi bumi $\left(a=g=9,8 \mathrm{~ms}^{-2}\right)$.

Untuk kasus jatuh bebas, besar kecepatan diperoleh dengan persamaan 2.6.

$$
V=\sqrt{2 g \cdot h}
$$

dimana

$\mathrm{v}=$ kecepatan benda jatuh bebas, $(\mathrm{m} / \mathrm{s})$.

$\mathrm{g}=$ gaya grafitasi, $\left(\mathrm{m} / \mathrm{s}^{2}\right)$.

$\mathrm{h}=$ ketinggian jatuh benda, $(\mathrm{m})$.

\section{Teori Momentum dan Impuls}

Sebuah benda bergerak dikatakan mempunyai momentum yang dinyatakan dengan hasil kali massa dengan kecepatan benda tersebut. Hal ini dapat dinyatakan dengan persamaan (2.8).

$$
M=m . v
$$

dimana

$$
\begin{aligned}
& \mathrm{M}=\text { momentum, }(\mathrm{kg} \cdot \mathrm{m} / \mathrm{s}) . \\
& \mathrm{m}=\text { massa, }(\mathrm{kg}) . \\
& \mathrm{v}=\operatorname{kecepatan},(\mathrm{m} / \mathrm{s}) .
\end{aligned}
$$

Impuls adalah lonjakan gaya tiba-tiba pada selang waktu waktu tertentu yang merupakan hasil kali gaya dengan selang waktu yang diperlukan. Ini dapat dinyatakan dalam persamaan (2.9). dimana:

$$
I=F . t
$$

$$
\begin{aligned}
& \mathrm{I}=\text { implus } \\
& \mathrm{F}=\operatorname{gaya}(\mathrm{N}) \\
& \mathrm{t}=\text { waktu }(\mathrm{s})
\end{aligned}
$$




\section{Porositas}

Porositas adalah besarnya persentasi ruang-ruang kosong atau besarnya kadar pori yang terdapat pada beton dan merupakan salah satu faktor utama yang mempengaruhi kekuatan beton. Pori-pori beton biasanya berisi udara atau berisi air yang saling berhubungan dan dinamakan dengan kapiler beton. Kapiler beton akan tetap ada walaupun air yang digunakan telah menguap sehingga kapiler ini akan mengurangi kepadatan beton yang dihasilkan. Dengan bertambahnya volume pori maka nilai porositas juga akan semakin meningkat dan hal ini memberikan pengaruh buruk terhadap kekuatan beton.

Beton mempunyai kecenderungan berisi rongga akibat adanya gelembung-gelembung udara yang terbentuk selama atau sesudah percetakan. Hal ini penting terutama untuk memproleh campuran yang mudah untuk dikerjakan dengan menggunakan air yang berlebihan daripada yang dibutuhkan guna persenyawaan kimia dengan semen. Air ini menggunakan ruangan dan bila kemudian kering akan menimbulkan rongga-rongga udara. Dapat ditambahkan bahwa selain air yang mengawali pemakaian ruangan dan kelak menjadi rongga, terjadi juga rongga-rongga udara langsung pada jumlah persentase yang kecil. Hal lain adalah terdapatnya pengurangan volume absolut dari semen dan air setelah reaksi kimia dan terjadi pengeringan sedemikian rupa sehingga pasta semen sudah kering akan menempati volume yang lebih kecil dibandingkan dengan pasta yang masih basah, berapapun perbandingan air yang digunakan [4].

\section{Metode Penelitian}

\section{Tempat dan Waktu}

Penelitian ini dilaksanakan dalam beberapa tahapan, yaitu seperti diuraikan pada Tabel 3.1.

Tabel 3.1. Lokasi dan aktivitas penelitian

\begin{tabular}{|c|c|c|}
\hline No & Aktifitas & Lokasi Penelitian \\
\hline 1. & $\begin{array}{l}\text { Pembuatan } \\
\text { serat TKKS }\end{array}$ & $\begin{array}{l}\text { Pusat Riset IMPak } \\
\text { dan Keretakan, Dept. } \\
\text { Teknik Mesin, FT- } \\
\text { USU. }\end{array}$ \\
\hline 2. & $\begin{array}{l}\text { Pembuatan } \\
\text { batako } \\
\text { ringan } \\
\text { dicampur } \\
\text { serat } T K K S\end{array}$ & $\begin{array}{c}\text { Pusat Riset IMPak } \\
\text { dan Keretakan, Dept. } \\
\text { Teknik Mesin, FT- } \\
\text { USU. }\end{array}$ \\
\hline 3. & $\begin{array}{l}\text { Uji impak } \\
\text { jatuh bebas }\end{array}$ & $\begin{array}{c}\text { Pusat Riset IMPak } \\
\text { dan Keretakan, Dept. } \\
\text { Teknik Mesin, FT- } \\
\text { USU. }\end{array}$ \\
\hline 4. & $\begin{array}{c}\text { Analisa data } \\
\text { olah data }\end{array}$ & \\
\hline 5. & Simulasi & IC STAR \\
\hline
\end{tabular}


computer

\section{Alat dan Bahan}

Beberapa alat yang digunakan dalam penelitian ini adalah sebagai berikut:

- Alat uji impak jatuh bebas

- Horizontal shaft mixer

- Kompressor

- Foam generator

- Timbangan digital

- Wadah adukan

- Mesin penghalus serat

- Software Solidwork \& ANSYS

- Cetakan

- Gelas ukur

Bahan-bahan yang akan digunakan dalam penelitian ini adalah:

- Pasir

- Semen

- Air bersih

- Foaming agent

- Serat TKKS

\section{Proses Pembuatan Serat TKKS}

Serat TKKS diperoleh dari hasil pengolahan tandan kosong kelapa sawit dengan beberapa tahapan proses. Tahapan tersebut adalah:

1. Perendaman TKKS dalam air yang mengandung larutan $\mathrm{NaOH} 1 \%$ selama 24 jam.

2. Pencucian dengan air bersih.

3. Pengeringan dengan cara menjemur serat ini pada sinar matahari selama \pm 3 hari atau dapat juga menggunakan mesin pengering.

4. Pencacahan serat menjadi bagian-bagian kecil $(5$ s.d. $10 \mathrm{~cm})$.

5. Penghalusan serat dengan menggunakan mesin penghalus serat.

\section{Proses Pembuatan Batako Ringan}

Tahapan pembuatan batako ringan adalah sebagai berikut:

1. Pasir diayak untuk mendapatkan ukuran butir yang sama dan memisahkan partikel lain yang tidak dibutuhkan seperti kotoran kayu, daun kering, dll.

2. Semen diayak untuk memisahkan gumpalan-gumpalan semen yang disebabkan oleh kelembaban lingkungan penyimpanan.

3. Serat disiapkan dan ditimbang sesuai dengan komposisi yang telah ditentukan

4. Bahan-bahan ditimbang sesuai komposisi seperti ditunjukkan pada Tabel 3.2.

Tabel 3.2. Komposisi bahan dalam satuan gram

Seme Pasir Air Bahan TK




\begin{tabular}{|c|c|c|c|c|c|}
\hline $\mathrm{n}$ & & & Penge & bang & $\mathrm{KS}$ \\
\hline (1) & (2) & $(0,5)$ & $\begin{array}{c}\text { Foam } \\
(1)\end{array}$ & $\begin{array}{c}\text { Air } \\
(60) \\
\end{array}$ & $(4 \%)$ \\
\hline 5000 & 7500 & 2500 & 20,8 & 1080 & 500 \\
\hline
\end{tabular}

5. Mesin horizontal shaft mixer dihidupkan

6. Pasir, semen, dan serat TKKS diaduk ke dalam mesin horizontal shaft mixer sampair semua tercampur secara merata.

7. Air ditambahkan ke dalam campuran.

\section{HASIL DAN PEMBAHASAN}

\section{Hasil pembuatan batako ringan.}

Batako ringan yang dicetak mempunyai ukuran panjang $600 \mathrm{~mm}$, lebar $200 \mathrm{~mm}$ dan tinggi $100 \mathrm{~mm}$ dapat dilihat pada Gambar.

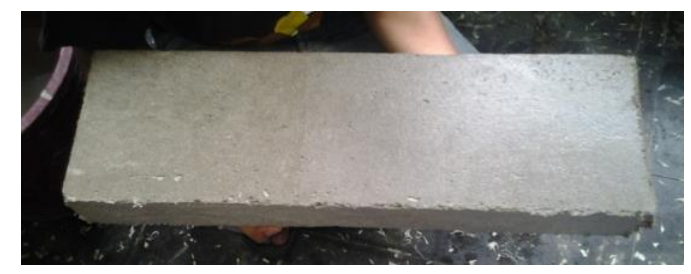

Pada gambar di atas merupakan bentuk wujud batako ringan hasil cetakan berbentuk persegi panjang dengan dimensi ukuran tertera pada penjelasan di atas.

\section{Pengujian dengan ketinggian $0,5 \mathrm{~m}$}

Grafik gaya impak pada spesimen posisi datar dengan ketinggian 0,5 meter, diperlihatkan seperti pada Gambar.

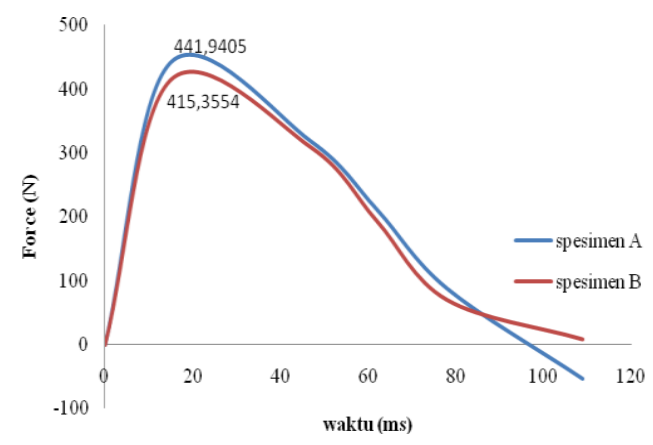

Hasil dari pengujian eksperimental yang dilakukan dengan pengujian impak jatuh bebas batako ringan dapat ditunjuk pada Gambar.
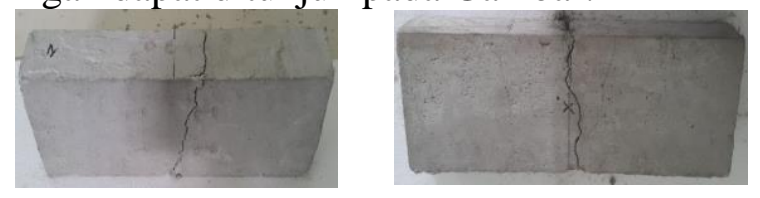
Dari Gambar dapat dilihat bahwa untuk kategori gaya impak ketinggian 0,5 meter untuk spesimen A diperoleh gaya impak sebesar 441,9405 N dan spesimen B sebesar 415,3554 N. Pada ketinggian $0,5 \mathrm{~m}$ terjadi patah tengah pada spesimen.

\section{Pengujian dengan ketinggian 1 m}

Grafik gaya impak pada spesimen posisi datar dengan ketinggian 1 meter, diperlihatkan seperti pada Gambar.

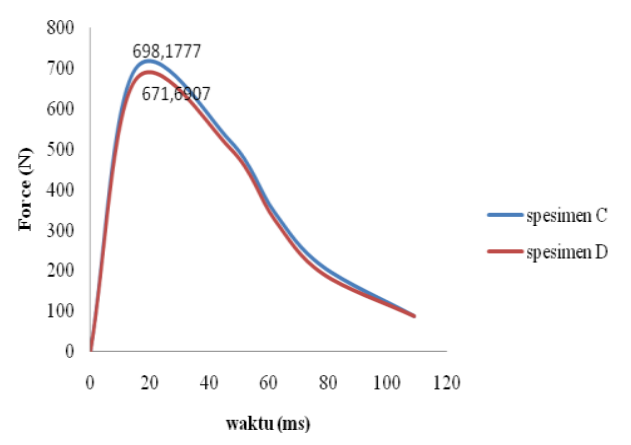

Hasil dari pengujian eksperimental yang dilakukan dengan pengujian impak jatuh bebas batako ringan dapat ditunjuk pada Gambar.
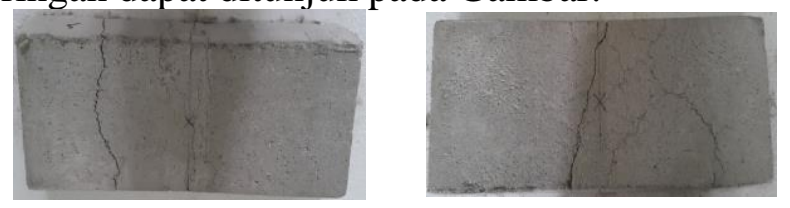

Dari Gambar dapat dilihat bahwa untuk kategori gaya impak ketinggian 0,5 meter untuk spesimen C diperoleh gaya impak sebesar 698,1777 N dan spesimen D sebesar 671,6907 N. Pada ketinggian $1 \mathrm{~m}$ terjadi patah tengah pada spesimen.

\section{Pengujian dengan ketinggian 1,5 m}

Grafik gaya impak pada spesimen posisi datar dengan ketinggian 1,5 meter, diperlihatkan seperti pada Gambar.

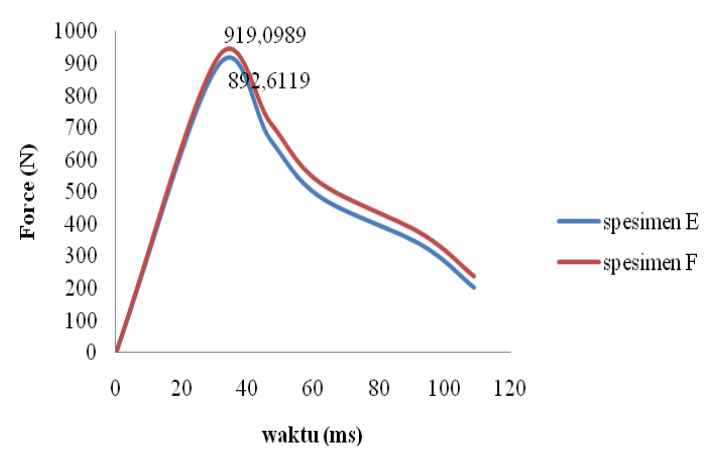

Hasil dari pengujian eksperimental yang dilakukan dengan pengujian impak jatuh bebas batako ringan dapat ditunjuk pada Gambar. 

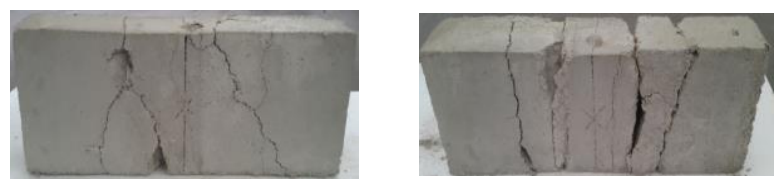

Dari gambar terlihat bahwa untuk kategori impak ketinggian 1,5 meter untuk spesimen E diperoleh gaya impak sebesar 892,6119 N dan spesimen F sebesar 919,0989 N. Pada ketinggian 1,5 m terjadi patah pada spesimen.

Untuk menghitung besar tegangan spesimen, dapat digunakan persamaan 4.1 berikut.

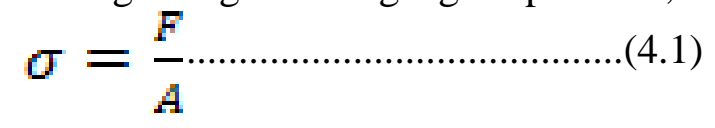

\section{Tegangan lentur anvil}

Suatu batang yang dikenakan oleh beban-beban yang bekerja secara transversal terhadap sumbu pemanjangannya. Beban-beban ini menciptakan aksi internal, atau resultan tegangan dalam bentuk tegangan normal,tegangan geser dan momen lentur.

Hasil penelitian menunjukkan adanya tegangan lentur yang terjadi pada anvil sewaktu batako ringan dijatuhkan dari ketinggian tertentu saat pengujian impak jatuh bebas. Tegangan lentur yang terjadi pada anvil dapat dilihat pada Gambar.

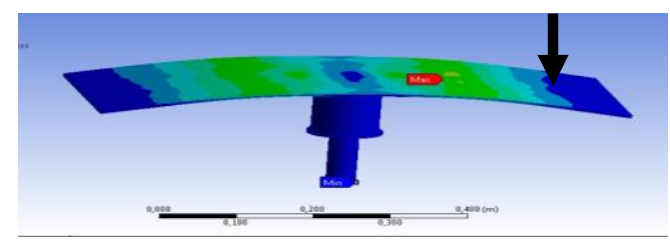

Maka rumus untuk mencari besar tegangan lentur pada anvil adalah:

$$
\sigma=\frac{\left(m \cdot g \cdot l a+\frac{F}{3} \cdot \frac{l b}{3}\right) \cdot\left(\frac{b}{2}\right)}{\frac{1}{12} \cdot l b \cdot b^{3}}
$$

Dimana :

$\mathrm{m}=$ massa anvil, $(\mathrm{kg})$

$\mathrm{g}=$ gaya gravitasi, $\left(\mathrm{m} / \mathrm{s}^{2}\right)$

la = panjang anvil, $(\mathrm{m})$

$\mathrm{f}=$ gaya, (newton)

$\mathrm{b}=$ tebal plat anvil (m)

$\mathrm{lb}=$ panjang batako $(\mathrm{m})$

Hasil perhitungan tegangan impak pada batako dan tegangan lentur pada anvil dapat dilihat pada tabel dibawah. 


\begin{tabular}{cccc}
\hline $\begin{array}{c}\text { Spesime } \\
\mathbf{n}\end{array}$ & $\begin{array}{c}\text { Ketinggi } \\
\text { an } \\
\text { (meter) }\end{array}$ & $\begin{array}{c}\text { Tegang } \\
\text { an } \\
(\mathbf{M P a})\end{array}$ & $\begin{array}{c}\text { Teganga } \\
\mathbf{n} \\
\text { Lentur } \\
\text { (MPa) }\end{array}$ \\
\hline $\mathrm{A}$ & 0,5 & 0,0036 & 9,1 \\
$\mathrm{~B}$ & 0,5 & 0,0034 & 7,1 \\
$\mathrm{C}$ & 1 & 0,0058 & 13,1 \\
$\mathrm{D}$ & 1 & 0,0056 & 12,7 \\
$\mathrm{E}$ & 1,5 & 0,0074 & 16,2 \\
$\mathrm{~F}$ & 1,5 & 0,0076 & 16,6 \\
\hline
\end{tabular}

\section{Makrostruktur}

\section{Hasil makrostruktur pada permukaan batako ringan}

Hasil produk batako ringan yang dianalisa makrostruktur permukaannya menggunakan aplikasi ImageJ dapat dilihat pada Gambar.

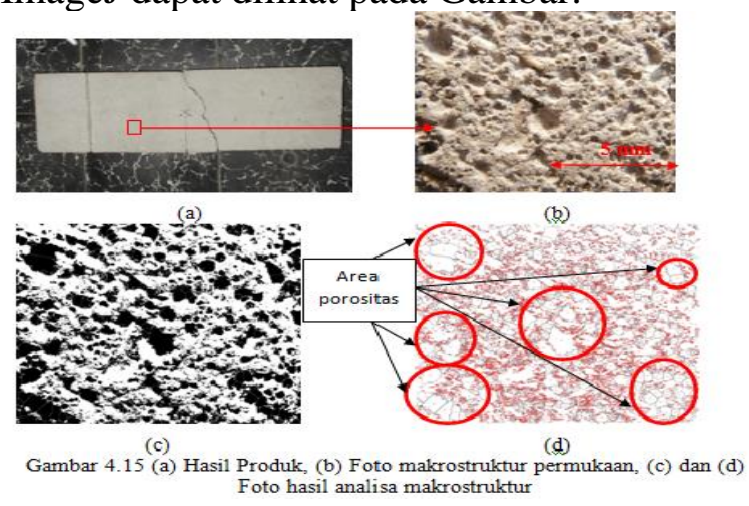

Berdasarkan hasil analisa makrostruktur bagian permukaan batako ringan dengan ukuran $10 \times 10$ mm yang ditunjukkan pada Gambar (d),ditemukan 30 titik porositas dengan area 15,64\% per 100 $\mathrm{mm}^{2}$ penampang permukaan. Besar porositas yang dapat diterima atau ditoleransi pada permukaan sebesar $0,08 \mathrm{~mm}^{2}$. Prositas yang terjadi diakibatkan kandungan air dan udara pada struktur batako ringan yang membentuk rongga-rongga kosong pada penampang permukaan batako ringan tersebut.

\section{Hasil makrostruktur pada potongan dalam batako ringan}

Berikut merupakan foto hasil makrostruktur pada potongan dalam batako ringan yang ditujukan pada Gambar. 


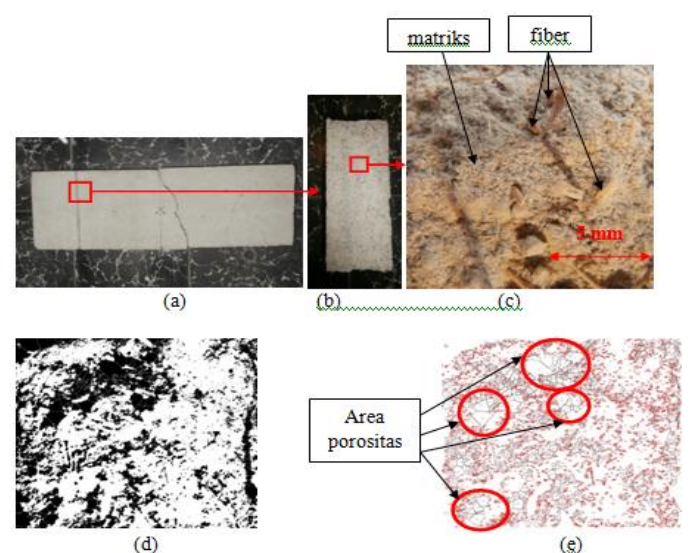

Pada penampang permukaan area porositas sebesar 15,64 \% lebih besar dari pada penampang bagian dalam yaitu sebesar 9,45\%. Besarnya porositas pada penampang permukaan karena pengaruh dari cetakan batako ringan dan pada saat penungang ke dalam cetakan yang tidak merata. Akibatnya gelembung udara tidak terdistribusi dengan baik dan membentuk rongga-rongga kosong.

\section{Hasil makrostruktur pada patahan batako ringan}

Berikut merupakan foto hasil makrostruktur pada patahan batako ringan yang ditujukan pada gambar.
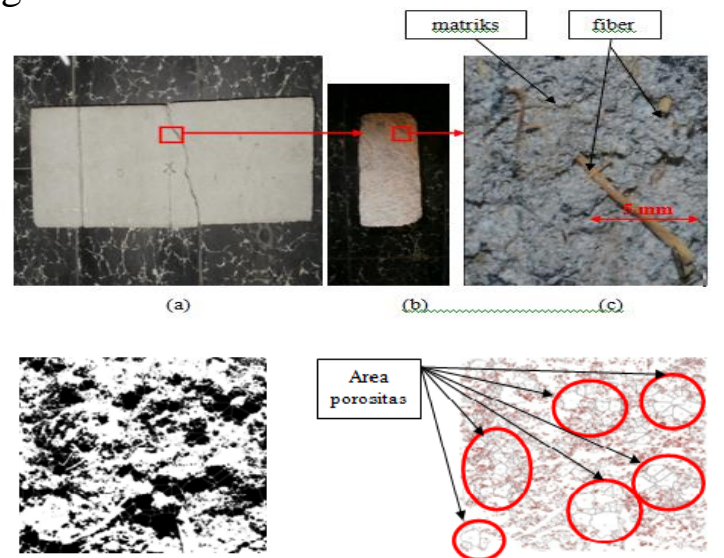

(d)

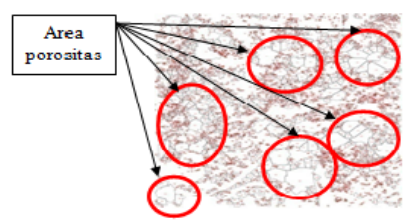

(e)

Gambar 4.17 (a) Spesimen yang patah, (b) Penampang dalam spesimen, (c) Foto makrostruktur bagian dalam, (d) dan (e) Foto hasil analisa makrostruktur

Ditemukan 40 titik porositas dengan area 20,45\% per $100 \mathrm{~mm}^{2}$ penampang permukaan potongan batako ringan. Besar porositas yang dapat diterima pada patah sebesar $0,09 \mathrm{~mm}^{2}$.

\section{Kesimpulan}

Kesimpulan yang diperoleh dari hasil penelitian yang dilakukan yakni:

1. Hasil pengujian pada batako ringan yang dikenai beban impak jatuh bebas.Pada ketinggian 0,5 $\mathrm{m}$ spesimen A nilai Fmax =441,94 $\mathrm{N}$, Tegangan =0,0036 Mpa, Tegangan lentur $=9,1 \mathrm{MPa}$, dan Energi impak yang diserap $=136$ Joule. Spesimen $\mathrm{B}$ nilaiFmax $=$ 415,35 N, Tegangan $=0,0034 \mathrm{Mpa}$, Tegangan lentur $=7,1 \mathrm{MPa}$ dan Energi impak yang diserap $=74$ Joule . Pada ketinggian $1 \mathrm{~m}$ terjadi patah. Pada ketinggian $1 \mathrm{~m}$ spesimen $\mathrm{C}$ nilai Fmax $=698,17 \mathrm{~N}$, Tegangan $=0,0058 \mathrm{Mpa}$, Tegangan lentur $=13,1 \mathrm{MPa}$, dan Energi impak 
yang diserap $=536$ Joule. Spesimen $\mathrm{D}$ nilaiFmax $=671,69 \mathrm{~N}$, Tegangan $=0,0056 \mathrm{Mpa}$, Tegangan lentur $=12,7 \mathrm{MPa}$ dan Energi impak yang diserap =513 Joule. Pada ketinggian 1 $\mathrm{m}$ terjadi patah. Pada ketinggian 1,5 m spesimen E nilai Fmax. = 892,61 N, Tegangan = 0,0074 Mpa,Tegangan lentur = 16,2 MPa dan Energi impak yang diserap $=1101$ Joule . Spesimen F nilai Fmax. $=$ 919,09 N, Tegangan = 0,0076 Mpa, Tegangan lentur $=16,6 \mathrm{MPa}$ dan Energi impak yang diserap $=1136$ Joule . Pada ketinggian 1,5 m terjadi patah.

2. Makrostruktur

Porositas yang terjadi pada permukaan batako ringan $=15,64 \%$ per $100 \mathrm{~mm}^{2}$. Besar porositas yang dapat diterima atau ditoleransi pada permukaan sebesar $0,08 \mathrm{~mm}^{2}$. pada potongan bagian dalam $=9,48 \%$ per $100 \mathrm{~mm}^{2}$ Besar porositas yang dapat diterima pada potongan sebesar $0,02 \mathrm{~mm}^{2}$. pada patahan $=20,45 \%$ per $100 \mathrm{~mm}^{2}$ Besar porositas yang dapat diterima pada patah sebesar $0,09 \mathrm{~mm}^{2}$. Maka, rata-rata area porositas pada spesimen batako ringan $=$ $15,19 \%$.

\section{Ucapan Terima Kasih}

Penelitian ini masuk dalam salah satu proyek MP3EI (Masterplan Percepatan dan Perluasan Pembangunan Ekonomi Indonesia). Terima kasih kepada MP3EI atas dukungannya kepada peneliti selama penelitian ini berlangsung. Penulis mengucapkan terima kasih kepada Bapak Ade Irwan, ST, Bapak Yusuf, Bapak Nuzuli, Bapak Irwansyah dan seluruh anggota IFRC yang telah membantu penulis dalam pembuatan dan penelitian ini.

\section{Daftar Pustaka}

[1] Basuki, Achmad. Material Komposit.PT. Pradya Paramita. Jakarta. 2012.

[2] Isroi, Pengolahan TKKS (Tandan Kosong Kelapa Sawit), 1998.

[3] NuzuliFitriadi, Penyelidikan Perilaku Mekanik Material Concrete Foam Diperkuat Serat TKKS Terhadap Beban Statik Dan Impak, Universitas Sumatera Utara, 2014. Tesis pada Magister Teknik Mesin USU Medan: tidak diterbitkan.

[4] L.J. Murdock dan K.M. Brook (Alih bahasa Stepanus Hendarko). 1991. Bahan dan Praktek Beton. Jakarta: Erlangga.

[5] Sperling, L.H. Introduction to Physical Polymer Science. John Wiley \& Sons, Inc. New York.1986. 


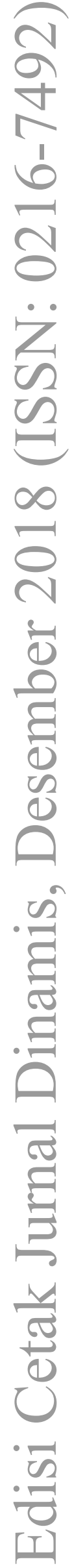

